\title{
Social factors and quality attributes influencing preference for production of local poultry in Butaleja and Tororo, eastern Uganda
}

\author{
James. Higenyi ${ }^{1,}$, John. David. Kabasa ${ }^{1}$, Charles. Muyanja ${ }^{2}$ \\ ${ }^{1}$ College of Veterinary Medicine, Animal Resources and Bio-security, Makerere University, Kampala, Uganda \\ ${ }^{2}$ College of Agriculture and Environmental Sciences, Makerere University, Kampala, Uganda
}

\section{Email address:}

higenyijames9@gmail.com (J. Higenyi)

\section{To cite this article:}

James. Higenyi, John. David. Kabasa, Charles. Muyanja. Social Factors and Quality Attributes Influencing Preference for Production of Local Poultry in Butaleja and Tororo, Eastern Uganda. Animal and Veterinary Sciences. Vol. 2, No. 1, 2014, pp. 10-17. doi: $10.11648 /$ j.avs.20140201.13

\begin{abstract}
Micronutrient deficiency is prevalent among the low-income rural and peri-urban dwellers in Uganda, largely attributed to decreasingly adequate intake of food of animal origin. The aim of this study was to determine the sociocultural factors that influence preference for production of local poultry in Butaleja and Tororo districts. A total of 193 respondents comprising poultry farmers (178) and extension workers (15) were interviewed using valid structured questionnaire. The results of survey revealed that $74.5 \%$ of respondents were male, majority of whom were above 39 years $52.2 \%$. More significantly preference for production was influenced by economic value $78.5 \%$. Turkey was ranked most valued source of income $82.3 \%$ while duck meat 76.7 \%source of food in rural families. Disease incursions $71.4 \%$ and difficulty to manage $73.4 \%$ were significant $(\mathrm{p}<0.001)$ aversion factors. Further, results showed that knowledge was infrequently transferred to duck enterprise $93.3 \%$. The most significant $(\mathrm{p}<0.001)$ challenge was diseases and pests at 95.5\%. The logistic regression model indicated high preference for important value as source of household income, the most robust predicator of likelihood of producing local poultry. Similarly, the model demonstrated that farmers' dislike was strongly attributed to lack of knowledge and skills and beliefs. In conclusion preference for local poultry production depends on social values as source of income. In addition duck meat is increasingly becoming a significant source of food in rural families. Therefore, we suggest further indepth studies, beliefs updating and poultry sector support.
\end{abstract}

Keywords: Local Poultry, Preference, Social Values, Beliefs Updating, Agricultural Support Policy

\section{Introduction}

Poultry production supplements many agricultural economies of developing countries through food security and poverty reduction [9]. In Uganda, the relative importance of poultry industry particularly traditional poultry in the livelihoods of the low income families (rural and peri-urban) is fundamental $[6,8]$. Worldwide the demand for the animal source foods is growing, particularly in developing countries due to income growth, urbanization and population growth $[5,11]$. In Uganda, local poultry meat especially chicken has increasingly dominated the local markets with estimation of $80 \%$ of the total poultry meat [8]. However, the consumption of especially chicken meat in poor rural families has been declining due to increasingly high price [5]. For instance, of the total poultry meat in the markets, $80 \%$ is consumed by effluent urban and semi-urban dwellers due to income growth and high purchasing power [22] while low-income rural families' consumption was 7\% [9]. This notwithstanding, Uganda is one of the developing countries where malnutrition and nutrition problems still exist estimated at $27 \%$ and $25 \%$ in the poorer rural and urban families respectively $[20,29]$. This situation was more significant in homes without animals [31]. Of the malnutrition problems however, micronutrient deficiencies are increasingly becoming more significant in poor rural households [5]. For example, high frequency of vitamin $\mathrm{A}$, vitamin $\mathrm{B}-12$, riboflavin deficiency; iron, zinc, and calcium deficiencies are prevalent [12]. Further, it is estimated that children under 5 years in rural areas, $38 \%$ suffer from chronic malnutrition (stunting), 16\% underweight and 6\% acute malnutrition [4] while $30-40 \%$ severely malnourished children are HIV 
positive (1). In addition, the rural families experience higher prevalence of vitamin A deficiency among women $19 \%$ and children $20 \%$ [20].

The deficiency of dietary micronutrients is more significantly associated with inadequate consumption of foods of animal origin, which contain high amount of available micronutrients [5]. For generations, local poultry has been used in rural communities to supplement households with animal proteins and source of income [7, 16, 18]. Unfortunately, commercialization of local chicken is problematic. As a result, supply is not equal to demand and low income families in rural and peri-urban areas with deteriorating purchasing power are actually decreasingly consuming foods of animal origin. Further, turkeys and ducks with high potential as alternative sources of animal source foods are equally underutilized. They are apparently neglected by national agricultural policies evidenced by little attention and support $[12,17,30]$. This is attributed to a number of factors, of which some have socio-cultural and religious roots. The most important by far, however, is preference for the poultry types and their products. It is acknowledged that preference depends on individual inherent interest, traditions, incomplete understanding of their nutritional potentiality and perception of quality attributes of the products [7,30]. Currently, there is scanty information documented about the factors that influence preference for production of local poultry products in Uganda. Therefore, this research determined the main challenges, socio-cultural factors and quality attributes influencing preference for production of the selected local poultry meat types. Further, the study established the contribution of duck and turkey meat as source of food in the poor rural and peri-urban settings.

\section{Materials and Methods}

The research employed quantitative study designs to data collection. The research instrument used was structured questionnaire which was developed, pre-tested in rural communities of Mukono district to remove ambiguity and validate its comprehensiveness. The validated structured questionnaire was administered to randomly selected respondents to elicit the required information. Afield survey using validated structured questionnaire was administered to poultry keepers and extension staffs in the Butaleja and Tororo districts. A total of 193 respondents (178 as proxy for poultry keeping households and 15 extension workers) were interviewed.

Data from the field survey was checked for consistency, accuracy and completeness. Open ended and multiple questions were coded and the data was captured using Epidata software Version 3.1. The data was exported to STATA Data Analysis System version 11. Analysis was done at three level; univariate, bivariate and multivariate, involving both descriptive and inferential techniques. At univariate descriptive levels, the study presented frequencies, percentages and graphical displays, with cross tabulations
(Chi-square) being used to assess bivariate relationships. To determine the significant dependent variable of use of indigenous poultry products, a binary logistic regression was used to examine the odds ratios associated with various categorical levels of the dependent variables. Using univariate logistic regression, the likelihood function known as odds ratio was used to estimate probability of event of interest occurring (the probability that a farmer will rear local poultry). This is represented functionally as:

Odds ratios $=\frac{p}{1-p}$ (the ration of the probability of success to probability of failure). However, this probability varies from one respondent to the other; so we need a convention that captures all the respondents' individual probability by adding subscript $i$. Then link the odd ratio to linear predictors using a natural Logarithm function to arrive at prediction equation as below:

$$
\ln \left(\frac{p_{i}}{1-p_{i}}\right)=\alpha+\beta_{i} x_{i}+\varepsilon_{i}
$$

Descriptive analysis was exclusively conducted for data collected from extension worker.

\section{Results}

The results of survey revealed that $74.5 \%(n=117)$ of respondents were male, majority of whom were 40 years and above $52.2 \%(n=82)$. More than a half $(54.1 \%)$ of the respondents attended primary education. And of the five ethnic groups represented by respondents; Adhola (50.3\%) and Munyole (47.8\%) were predominant. The major religions were; Catholics (40.8\%) and Anglican (42.7\%). Whereas religion, tribe, location and education were significant $(\mathrm{p}<0.05)$; age and gender was very insignificant $(p>0.05)$ to production of the local poultry types. This was represented in table 1 below:

Interestingly, the respondents' production preference for local poultry species was premised on economic values and individual interest in production factors. The most important production preference criteria for the subsystems were: faster growth and high reproduction rate $37.0 \%(\mathrm{n}=34)$ and disease resistance and hardy $19.6 \%$ $(\mathrm{n}=18)$ for ducks, high economic value $78.5 \%(\mathrm{n}=62)$ for turkey while ease to manage $19.2 \%(n=30)$, market demand $14.1 \%(n=22)$ and availability of inputs $10.9 \%(n=17)$ for chicken. Though, ease to manage $10.9 \% \quad(n=10)$ was important for ducks too. Apparently, the reasons of production preference for local poultry were significantly important $(\mathrm{p}<0.001)$. This was illustrated in figure1 below.

In addition, the most significant aversion reasons towards production of the local poultry species were: lack of knowledge and technology 39.1\% $(n=36)$ for duck, difficulty to manage for turkey $73.4 \%(n=58)$ and diseases incursions for chicken $71.4 \% \quad(n=105)$. Although other factors like respondent's perception of poor sanitary 
conditions $26.1 \%(\mathrm{n}=24)$, limited market $7.6 \%(\mathrm{n}=7)$ and beliefs $2.2 \%(n=2)$ were not very much rated, they are important de-motivation factors on the side of duck production. Interestingly however, there are no cultural and religious ramifications to local poultry production. These driving forces for development of negative attitude towards local poultry production were statistically very significant to duck subsystem $(\mathrm{p}<0.001)$ and insignificant to local chicken and turkey production $(p>0.05)$. These responses were presented in figure 2 below:

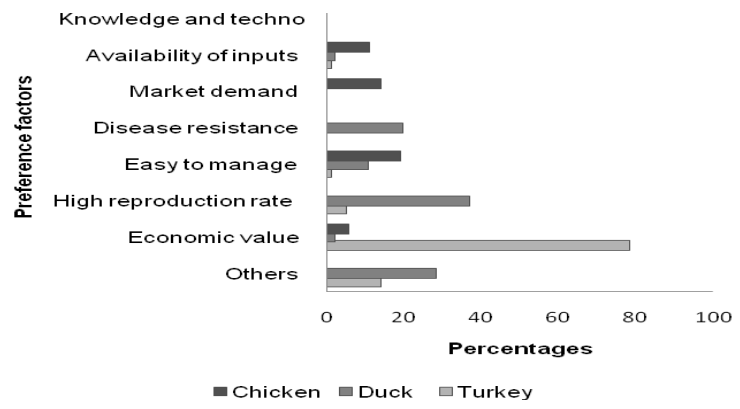

Figure 1. Important determinants of preference for production of local poultry species.

Table 1. The distribution of socio-demographic factors influencing production of local poultry.

\begin{tabular}{|c|c|c|c|}
\hline $\begin{array}{l}\text { Variables } \\
\text { (predicator) }\end{array}$ & $\begin{array}{l}\begin{array}{l}\text { Chicken } \\
(\mathrm{n}, \%)\end{array} \\
\end{array}$ & Turkey (n, \%) & Duck (n, \%) \\
\hline \multicolumn{4}{|l|}{ District } \\
\hline Tororo & $77(49.4)$ & $49(60.0)$ & $55(60.4)$ \\
\hline Butaleja & $79(50.6)$ & $30(38.0)$ & $36(39.6)$ \\
\hline \multicolumn{4}{|l|}{ Gender: } \\
\hline Male & $117(74.5)$ & $58(72.5)$ & $63(68.5)$ \\
\hline Female & $40(25.5)$ & $22(27.5)$ & $29(31.6)$ \\
\hline \multicolumn{4}{|l|}{ Age: } \\
\hline$<20$ & $2(1.3)$ & $1(1.3)$ & $2(2.2)$ \\
\hline $20-26$ & $22(40.0)$ & $9(11.3)$ & $12(13.0)$ \\
\hline $30-39$ & $51(32.5)$ & $29(36.3)$ & $29(31.6)$ \\
\hline $40+$ & $82(52.2)$ & $41(51.3)$ & $49(53.3)$ \\
\hline \multicolumn{4}{|l|}{ Tribe: } \\
\hline Adhola & $79(50.3)$ & $51(63.8)$ & $57(62.0)$ \\
\hline Ateso & $1(0.6)$ & $0(0.0)$ & $0(0.0)$ \\
\hline Muganda & $2(1.3)$ & $0(0.0)$ & $0(0.0)$ \\
\hline Munyankole & $0(0.0)$ & $1(1.3)$ & $0(0.0)$ \\
\hline Munyole & $75(47.8)$ & $28(35.0)$ & $35(38.0)$ \\
\hline \multicolumn{4}{|l|}{ Religion: } \\
\hline Anglican & $67(42.7)$ & $33(41.3)$ & $46(50.0)$ \\
\hline Born again & $5(3.2)$ & $0(0.0)$ & $1(1.1)$ \\
\hline Catholic & $64(40.8)$ & $39(48.8)$ & $39(42.4)$ \\
\hline Moslem & $21(13.4)$ & $8(10.0)$ & $6(6.5)$ \\
\hline \multicolumn{4}{|l|}{ Education: } \\
\hline Primary & $85(54.1)$ & $46(57.5)$ & $50(54.4)$ \\
\hline O'level & $35(22.3)$ & $23(28.8)$ & $28(30.4)$ \\
\hline High level & $5(3.2)$ & $2(2.5)$ & $3(3.6)$ \\
\hline Certificate & $22(13.4)$ & $6(7.5)$ & $7(7.6)$ \\
\hline Diploma & $11(7.0)$ & $3(3.8)$ & $4(4.4)$ \\
\hline
\end{tabular}

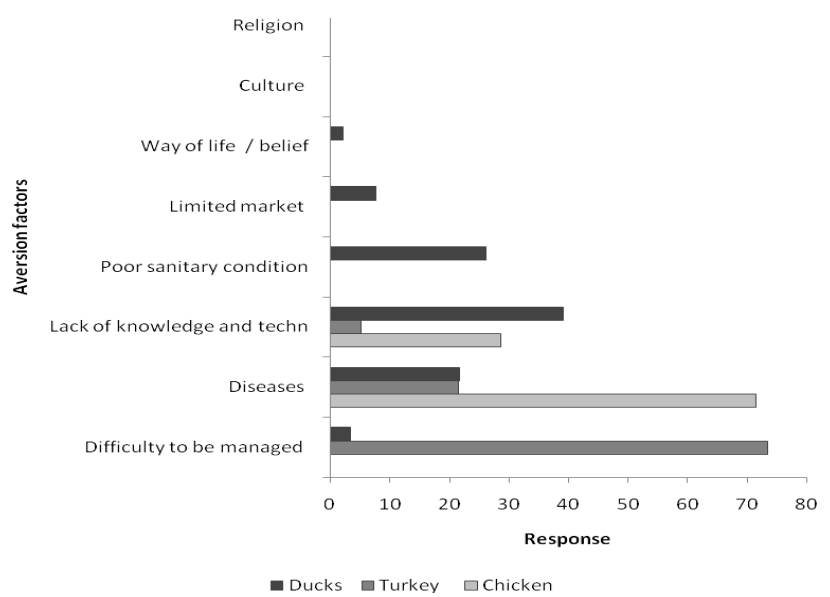

Figure 2. Factors influencing attitude towards rearing of local poultry types.

Regarding the most significant values attached to local poultry, available market services, awareness and access to knowledge, the results showed that farmers' awareness of the local poultry types was highly rated by extension staffs represented by universal rearing of all subsystems $100 \%$ $(n=15)$. Further, farmers expressed four important values attached to local poultry namely: source of food, income source, use for exchange and cultural use. Of these, respondents mostly valued chicken $83.3 \%(\mathrm{n}=130)$, turkey $95 \%(n=76)$ and duck $65.6 \%(n=59)$ as source of income in rural families. The relative importance of the local poultry types as source of food in rural families was demonstrated in terms of frequency of consumption and attached value. A bout $34.4 \%(n=31)$ of respondents valued duck as a more important source of food (animal proteins) as compared to chicken and turkey meat. Similarly, most of the extension workers presented duck meat as important source of food in families 73.3\% $(\mathrm{n}=11)$. More significantly $(\mathrm{p}<0.05)$ duck meat is increasingly consumed by rural families $76.7 \%$ $(n=69)$ followed by chicken $51.0 \%(n=79)$. However, more than a half of respondents never eat turkey meat at all in a month; 88.6\% $(\mathrm{n}=70)$. Chicken was also considered important for exchange $10.9 \%(\mathrm{n}=17)$ and cultural use $1.9 \%(n=3)$. Further, the study revealed that over $21 \%$ of respondents often access knowledge and skills (vaccination and treatments) on local chicken and turkey production while those engaged in duck production almost never access knowledge presented by $1.10 \%(n=1)$. A ware of the fact that access to potential buyers is crucial to stimulate production and many researchers have expressed limited market as a hindrance to the local poultry production, particularly ducks and turkey. As such, it was investigated and interestingly the results revealed the main market service providers as farmers and traders. Of which traders were predominant; duck $72.1 \% \quad(\mathrm{n}=62)$; turkey $94.7 \%$ $(n=71)$ and chicken $93.9 \%(n=139)$. Although the major marketing channel was farm gate; it was highly significant for ducks production $(\mathrm{p}<0.05)$. Apparently, results show that rural families are economically benefiting from local poultry. Besides, the $\mathrm{X}$ access to market services is a 
motivation to improve duck production over time. These findings were illustrated in figure 3 below:

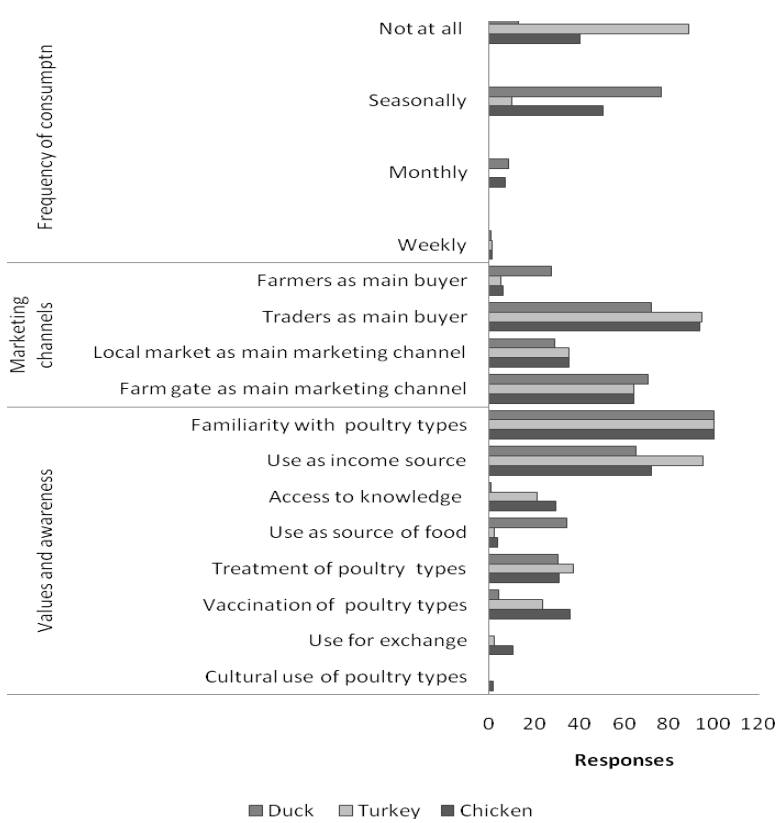

Figure 3. Important social values, awareness, marketing and frequency of consumption.

Assessing access to knowledge and skills by respondents, the results shows that there was significant variation in accessibility of knowledge among the poultry subsystems. This probably was linked to the frequency of contact with extension staffs and level of provision of advisory services. The results show that majority of extension staff regularly contact farmers to provide services on chicken production $33.3 \%(n=5)$ and they rarely contact farmers to provide services on turkey production $75 \%(n=6)$. The majority of them never contact farmers to provide service on ducks production $81.8 \%(n=9)$. Further, more than half of extension staffs $53.3 \% \quad(n=8)$ provide knowledge on production and management of sub-systems through trainings; chicken $93.3 \%(n=14)$ and turkey $28.6 \%(n=7)$. In contrast, duck enterprise was never considered represented by $93.3 \%(n=14)$. The technologies most frequently transferred to poultry keepers are treatment and vaccination; chicken $64.3 \% \quad(n=9)$ and $35.7 \% \quad(n=5)$ respectively. This provision of knowledge and skills was significant to turkey production $(p<0.05)$. However, the study further revealed that majority of extension staff charge treatment and vaccinations services $100 \%(n=14)$. Perhaps this was a major motivation to knowledge and technology transfer to sub-systems and was particularly very significant to duck subsystem $(\mathrm{p}<0.05)$. Nevertheless, other poultry services like marketing and processing/value addition were infrequently done. These results for evaluation of frequency of contact with extension staffs and knowledge and technology transferred were presented in the figure4 shown below:

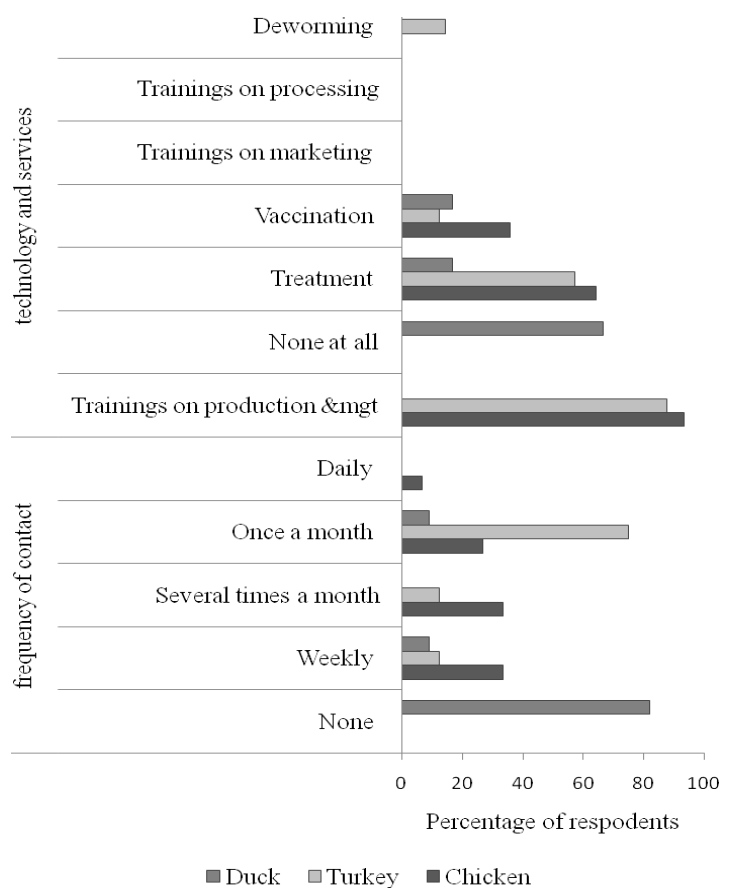

Figure 4. Transferred technology, services and frequency of contact between extension staffs and poultry farmers.

Interestingly however, the findings of overall rating for accessibility of knowledge by respondents were based on the following selected parameters: frequency of contact between extension workers and farmers, knowledge and technology transferred. As such, very effective meant respondents scored highly on assessment parameters, effective for moderate score and not effective least score or none at all. The majority of the respondents viewed accessibility of knowledge and skills as not effective for ducks $96.7 \%(n=89)$ and turkey $81.3 \%(n=65)$ while the rating were; effective $71.3 \%(\mathrm{n}=112)$ and very effective $28.7 \%(n=45)$ for chicken production. Accessibility of knowledge was statistically significant for turkey $(p<0.001)$ and insignificant for chicken and duck production. The main challenge to provision of education or knowledge on subsystems by extension workers was presented as: not planned for in government programes; turkey $71.43 \%(n=5)$ and duck $50 \%(n=7)$. Similarly, farmers' attitude and the religion of extension staffs also affected provision of services especially to duck production and was statistically significant $(\mathrm{p}<0.05)$. Furthermore, ranking the importance of the local poultry species in poverty alleviation (source of income) was assessed. The results showed ranking as: very important, turkey as $82.28 \%(\mathrm{n}=65)$; important, duck $45.5 \% \quad(\mathrm{n}=41)$, chicken $88.5 \% \quad(\mathrm{n}=138)$ and turkey $15.2 \%(\mathrm{n}=12)$ and little importance, duck 53.3\% $(\mathrm{n}=48)$, chicken $7.7 \%(n=12)$ and turkey $1.3 \%(n=1)$. Statistically these rankings were significant $(p<0.00 \mathrm{I})$ to production of the all the subsystems.

Generally, the major challenge to local poultry production was diseases and pests as represented by respondents per subsystem: chicken $95.5 \%(\mathrm{n}=148)$, turkey $37.5 \%(n=30)$ and ducks $56.8 \%(n=50)$. Moreover, this was 
very significant for chicken production $(p<0.001)$ and insignificant for turkey and ducks $(p>0.001)$. However, other significant factors for local chicken production included: lack of capital, insufficient feeds and lack knowledge and management skills.

\section{Logistic Regression Analysis Model}

This model predicated the effect of significant variables on local poultry production. The logistic regression results reported on the odd ratios, confidence interval and the probability values. In case of chicken production, it was observed that the Catholic had significantly increased odds of rearing chicken compared to the Anglicans representing a 2.8 increase in odds. Similarly, rural-urban farmers were more likely to rear chicken compared to the urban counterparts. However, much as the association was significant, the confidence interval was very wide, possibly affected by the majority of farmers coming from rural area the fact of a known distribution that more poultry farming takes place in the rural areas. The study also considered the reason for keeping chicken and farmers with commercial reason were more likely (increased odds of 16.2) to rear chicken compared to farmers who believe home consumption to be the most important reason for keeping chicken. The keeping chicken for exchange of purposes also weighed in as a reason for keeping chicken, accounted for by an increased odd of 0.5. Though, this level of association was insignificant. Further, it was observed that ranking the relevancy of chicken for house hold income was also significantly associated with the choice for rearing. Farmers who felt that chicken is important for family income had a significantly increased $(\mathrm{OR}=51.8)$ chance of rearing chicken compared to those who would rear chicken on no account. Those with little importance attached to chicken as family income source also had a relatively higher possibility $(\mathrm{OR}=18)$ of keeping chicken. This was illustrated in tables 2 below:

Table 2. Univariate Logistic Regression, farmers and the Chicken category.

\begin{tabular}{lll}
\hline Variable & Univariate OR(CI) & P-value \\
\hline $\begin{array}{l}\text { Religion } \\
\text { Anglican }\end{array}$ & 1 & \\
Catholic & $3.8(1.2-12)$ & 0.02 \\
Location & 1 & \\
Urban & $14.7(1.9-112.4)$ & 0.01 \\
Rural - Urban & & \\
Most important use of chicken & 1 & \\
Home Consumption & $17.2(1.5-33.7)$ & 0.01 \\
Sale & 1.5 & 0.765 \\
Exchange & & \\
Chicken for household income & 1 & 0.004 \\
No account & $18(2.5-131.3)$ & 0.000 \\
Little importance & $51.8(11.2-29.3)$ & 0.1 \\
Important & $9(0.7-122.8)$ & \\
Very Important &
\end{tabular}

Nevertheless, farmers were also interviewed on factors that influence their choice for rearing turkey and six variables were significantly associated with farmer's decision to keep turkeys namely; the districts of residence, tribe, education, access to knowledge, rating of knowledge access and ranking turkey as a source of household income. For instance, farmers from Tororo were less likely to keep turkey compared to their colleagues from Butaleja (OR reduced to 0.56); just like the Munyole compared to the Adhola tribe. Considering education and comparing all other levels to primary level, farmers with O'level qualification had increased possibility of rearing turkey with an odds ratio of 0.11 . More interestingly however, farmers with knowledge on how to rear turkey had 0.91 increased odds of keeping compared to those who confessed to lack the right knowledge. Similarly, farmers who rated their knowledge to be very effective were also significantly more (OR of 6.53) likely to rear turkey compared to their counterparts who felt their knowledge was just effective. Farmers who valued turkey to be very important household income source had 175.4 increased odds of keeping turkey as opposed to those who merely kept their bird on no account. This univariate logistic regressions output was illustrated in table 3 below:

Table 3. Univariate Logistic Regression, farmers and the Turkey category.

\begin{tabular}{|c|c|c|}
\hline Variable & Univariate OR (CI) & P-value \\
\hline \multicolumn{3}{|l|}{ District } \\
\hline Tororo & 1 & \\
\hline Butaleja & $0.44(0.23-0.81)$ & 0.009 \\
\hline \multicolumn{3}{|l|}{ Tribe } \\
\hline Adhola & 1 & \\
\hline Munyole & $0.44(0.24-0.84)$ & 0.012 \\
\hline \multicolumn{3}{|l|}{ Education level } \\
\hline Primary & 1 & \\
\hline O'level & $1.11(0.53-2.35)$ & 0.78 \\
\hline High School & $0.58(0.09-3.65)$ & 0.56 \\
\hline Diploma & $0.29(0.07-1.14)$ & 0.07 \\
\hline Others & $0.27(0.1-0.75)$ & 0.01 \\
\hline \multicolumn{3}{|c|}{ Knowledge on rearing turkey } \\
\hline Yes & 1 & \\
\hline No & $0.09(0.02-0.39)$ & 0.001 \\
\hline \multicolumn{3}{|c|}{ Rating knowledge access } \\
\hline Effective & 1 & \\
\hline Very effective & $6.53(1.82-23.54)$ & 0.004 \\
\hline \multicolumn{3}{|c|}{$\begin{array}{l}\text { Turkey as household income } \\
\text { source }\end{array}$} \\
\hline No account & 1 & \\
\hline Little importance & $28.5(1.27-638.89)$ & 0.035 \\
\hline Important & $136.79(14.63-1279.2)$ & 0.000 \\
\hline Very Important & $176.43(23-1353)$ & 0.000 \\
\hline
\end{tabular}

Besides, farmer's responses on factors influencing duck production were captured and the results of univariate logistic regression analysis had nearly similar outcomes on some variables like turkey. It was however, observed that Butaleja farmers had a significantly reduced chance of keeping ducks compared Tororo farmers (OR reduction of 0.56). And the Adhola tribe was found to be more likely to rear ducks compared to the Munyole (increased odds of 0.54). Interestingly, this study found urban farmers to significantly have higher possibility of keeping duck, evidenced by a 0.61 increased odds in favour of the urban farmers. on contrary to the finding for chicken and the 
turkey categories, the farmers who attached little importance to ducks as source of household incomes had a 293 increased odds of rearing ducks. Although, there could have been curvilinear tendencies in the data and which could explain the unusually large confidence interval. Farmers who held faster growth and high reproduction rate as a driving force to rearing ducks had the highest possibility of keeping ducks. In addition, farmers were also interviewed on the factors that interfere with their choices/interventions to rear ducks and it emerged that poor sanitation, feeding behaviour, beliefs and attitude, lack of knowledge and skills were very significant in discouraging farmers. These findings are represented in the table 4 below:

Table 4. Univariate Logistic Regression, farmers and the Ducks category.

\begin{tabular}{|c|c|c|}
\hline Variable & Univariate OR (CI) & P-value \\
\hline \multicolumn{3}{|l|}{ District } \\
\hline Tororo & 1 & \\
\hline Butaleja & $0.44(0.24-0.82)$ & 0.01 \\
\hline \multicolumn{3}{|l|}{ Tribe } \\
\hline Adhola & 1 & \\
\hline Munyole & $0.46(0.24-0.87)$ & 0.017 \\
\hline \multicolumn{3}{|l|}{ Location } \\
\hline Urban & 1 & \\
\hline Rural-Urban & $0.39(0.21-0.73)$ & 0.003 \\
\hline \multicolumn{3}{|l|}{ Duck as household income source } \\
\hline No account & 1 & \\
\hline Little importance & $294(35.4-2441.1)$ & 0.000 \\
\hline Important & $\begin{array}{l}133.9(16.96- \\
1057.49)\end{array}$ & 0.000 \\
\hline \multicolumn{3}{|l|}{$\begin{array}{l}\text { Most Important factor influencing } \\
\text { preference for Ducks }\end{array}$} \\
\hline Faster growth \& high prolific rate & 1 & \\
\hline Disease resistance and hardy & $2.12(0.53-8.48)$ & 0.289 \\
\hline Economic value & $0.24(0.03-1.58)$ & 0.14 \\
\hline Other factors & $0.16(0.07-0.37)$ & 0.000 \\
\hline \multicolumn{3}{|l|}{$\begin{array}{l}\text { Reasons stopping you from } \\
\text { keeping ducks }\end{array}$} \\
\hline $\begin{array}{l}\text { Poor Sanitation \& feeding } \\
\text { behaviour }\end{array}$ & 1 & \\
\hline Difficult to manage & $3.38(0.33-34.65)$ & 0.31 \\
\hline $\begin{array}{l}\text { Lack of knowledge and } \\
\text { technology }\end{array}$ & $2.25(1.02-4.95)$ & 0.04 \\
\hline Ways of life / belief & $0.13(0.03-0.63)$ & 0.01 \\
\hline Other reasons & $1.73(0.71-4.2)$ & 0.23 \\
\hline
\end{tabular}

\section{Discussion}

This present study has established the most significant determinants influencing preference for production of local poultry species as: social values, demographic and production factors. This is observed to be consistent with the others studies that place value on poultry as source of income, rituals and ceremonies [6, 7]. Focusing on the socio-demographic characteristics: religion, tribe, location were very significant determinants than age and gender. In other words, being a Catholic was associated with increased likelihood to rear chicken compared to the Anglicans. Similarly, rural-urban farmers were more likely to rear chicken compared to the urban counterparts while for ducks the reverse is true. This is linked to the established fact that duck and turkey production is concentrated around urban and peri-urban areas [28]. Further, being a Munyole and a residence of Butaleja is more significantly linked to duck and turkey production. This suggests that the tribe and location of residence of farmers determines participation in the subsystem and also indicates that resource availability differences influence preference for local poultry production. This is linked to the fact the socio-cultural dynamics influence preferences in societies [14]. Similarly, level of education was found to be important factor influencing farmer's interest in rearing turkey, though insignificant. For instance, the respondents education above O' level qualification was factor associated with more probability of rearing turkey. This was observed to concur with another study re-affirming that attaining post-secondary level education was very significant in increasing local chicken productivity [9]. Equally, it is recognized that farmers' basic knowledge influences decisions to select subsystems for production and its subsequent proper management [1, 25, 32]. Furthermore, the study revealed that majority of the respondents fell in youth age and elderly. Although age and gender were insignificantly linked to local poultry production, the finding strongly depicts the fundamental importance of local poultry in the livelihoods of the rural youth and old age people.

Further, demonstrates the potential of the poultry sector to improve because of the involvement of the trainable youth, majority of who have attained primary education. Although, contradicted with another study which reported a massive man power drift from rural to urban areas of people below age of 38 years in search of white-collar jobs resulting into reduced participation in local poultry production [2]. Interestingly, the results also showed that male gender is increasingly participating in local poultry production. This empirical result is linked to the fact that both male and female gender participate in local poultry production [10]. Further, emphasizes the relevancy of village poultry to men as preliminary stage of wealth creation and source of employment particularly to the less favoured areas in developing countries [7, 9, 25, 16, 17]. Similarly, the findings concur with the fact that rearing family poultry is more important traditional way of saving, insurance and investment [27].

Focusing on production factors, local poultry was perceived important value as income generating activity. Implying that respondents are more involved in local poultry production based on the accrued incomes and this was very significant. The other production factors such as high reproductive and growth rate, and resistance to disease were also important drivers of farmer's interest in duck production. However, perception of resistance to diseases and adoptability to environment is cited as one of the limitations to planned interventions in institutions [9]. Interestingly however, the relevancy of market structure was apparent in the study. The results showed increasing demand for all the poultry types. This growing demand and 
access to market services is a likely motivation to improve duck production over time.

In addition, the logistic regression model demonstrated that attitude was instrumental in respondents' aversion to participate in local poultry production. Beliefs were more significant than perceptions of poor sanitary conditions, lack of knowledge and technology in influencing attitude. These factors were more important to duck production than chicken and turkey. This fact was consistent with other studies $[5,7,21,31]$. Further, it's recognized that perceptions deter professional in engaging in poultry production [25]. Further, the empirical results revealed that there in increased awareness of local poultry because of being highly integrated and universally kept in the rural communities. More significantly local poultry was rated as major source household incomes and food. Further, duck and turkey subsystems in particular were significantly valuable as a source of food and income in the study areas. This is consistent with contemporary information emphasizing contribution of duck and turkey meat production to alleviation of poverty and reduction of hunger and improved food security in the poor rural families [13, 19, 24]. However, the study contradicts another study which revealed that ducks were rarely kept and infrequently consumed in rural families of Uganda [9]. Another factor of increasing importance to local poultry production was respondents' accessibility of knowledge and skills. The results showed that there are more frequent delivery of extension services to chicken subsystem than turkey and duck. Similarly, transferred technologies and services were mainly vaccinations, treatments and production and management practices. This offers explanation for the progressive increase in chicken production compared to turkey and ducks in Uganda. Unfortunately, knowledge and technology on marketing and value addition is never delivered. Probably this explains the low market demand for the duck meat and subsequent low production. Further, the results revealed that the main challenge to delivery of knowledge and technology was linked to inadequate technical skills by extension workers, attitude of both farmers and extension staff and failure to plan for the poultry subsystems in the government programmes. This was factual for another study [7]. Equally, other studies emphasized that recurrent neglect for the local poultry species is attributed to wrong agricultural policies, weak institutions and social structures $[9,30]$.

\section{Conclusions and Recommendations}

The present study has established that duck meat is frequently consumed in the rural families. As such, it is increasingly becoming a more important source of animal food. However, social values are increasingly associated with the likelihood to participate in local poultry production. In addition, beliefs and perceptions were observed to strongly influence attitude towards local poultry production, which, in turn influence individual preference for duck production than lack of knowledge and technology. Thus, we suggest the following: indepth studies, increase provision of information on nutritional and economic benefits of local poultry through education to influence change of attitude and beliefs (belief updating), improve on production and management practices of local poultry particularly duck and turkey and increase on poultry sector support.

\section{Acknowledgement}

The authors wish to thank the farmers and service providers from Butaleja and Tororo for their participation in the research. The study was funded by grant under the VASES-EDULINK program of the European Union.

\section{References}

[1] Adebaya, O.O. and Adeola, R.G. (2005). Socio-Economic Factors Affecting Poultry Farmers in Eligbo Local Government of Osun state. Journal of Human Ecology, 18(10):39-41

[2] Akinola, L.A.F. and George, S. (2008). Small-scale family poultry production as a substantial source of animal protein in selected local government areas in Rivers State. Journal of Agriculture and Social Research, 8(2):114

[3] Bachou, H., Thorkild, T., Downing, R. and Tumwine, J. (2006). Severe malnutrition with or without HIV-1 Infection in hospitalized children in Kampala, Uganda: differences in clinical features, haematological findings and CD4+ cell $\begin{array}{lll}\text { counts. Nutrition journal, } & \text { 5:27 }\end{array}$ (http://www.nutritritionj.com/content/5/1/27)

[4] FANTA-2 (2010). The Analysis of the Nutrition Situation in Uganda. Food and Nutrition Technical Assistance 11 Project (FANTA-2), Washington, DC: AED. www.fanta-2.org . Accessed on 6/10/2013.

[5] FAO (2002). Global Production and Consumption of Animal Source Foods. Presented at the conference "Animal Source Foods and Nutrition in Developing Countries" held in Washington, D.C.June 24-26.

[6] FAO (2003). Good practices in planning and management of intergrated commercial poultry production in Southern Asia. FAO Animal Production and Health Paper 159.

[7] FAO (2004). Small-scale poultry production. Technical guide, edited by E.B.Sonaiya \& S.E.J.Swan.Rome.ISSN $1810-1119$

[8] FAO (2008). Poultry Sector Country Review. Uganda. FAO Animal Production and Health Division www.fao.org/avianflu//en/farmingsystems.html. Accessed on $6 / 3 / 2012$

[9] FAO (2009b). The role of poultry in peoples livelihoods in Uganda. Prepared by state, A.E., Birungi, P.B., Haan, N. Rome: AHBL-Promoting Strategies for Prevention and Control of HPAI. http://www.fao.org/docrep/013/a1690e/a1690e00.pdf. Accessed 6/10/2013. 
[10] FAO (2009c). Poultry Genetic Resources and Small Poultry Production in Systems in Uganda. prepared by Busuulwa S. Henry. AHBL-promoting strategies for prevention and control of HPAI. Rome.

[11] FAO (2010). Poultry Meat and Eggs, agribusiness hand book. www.eastagri.org. Accessed on 4/3/2012.

[12] FAO (2010b). Uganda Nutrition Profile. Nutrition and Customer Protection Division. Food and Agriculture Organization of the United States. Accessed 6/10/2013. $\mathrm{ftp}: / / \mathrm{ftp}$.fao.org/ag/agn/nutrition/ncp/uga.pdf .

[13] FAOSTAT (2009). Top production indigenous poultry meat. http://faostat.fao.org. Accessed on 5/12/2011.

[14] Gossard, M.H. and York, R. (2003). Social Structural influence on meat consumption. Human Ecology Review, 10(1):1-9

[15] Gueye, E. F. (1998). "Village egg and fowl meat production in Africa". In: World's poultry Science Journal, 54:134

[16] Gueye, E.F. (2003).Gender issues in family poultry production systems in low-income food-deficit countries. American Journal of Alternative Agriculture 18(4): 185-195.

[17] Gueye, E.F. (2009). Small-Scale Family Poultry Production. The role of networks in information dissemination to family poultry farmers. World's Poultry Science Journal, 65:116

[18] Gueye, E.F. (2000). The role of family poultry in poverty alleviation, food security and promotion of gender equality in rural Africa. Outlook on Agriculture, 29(2):129-136

[19] Huda, N., Putra, A.A. and Ahmad, R. (2011). Potential Application of Duck Meat for Development of Processed Meat Products. Current Research in Poultry Science, 1:1-11. DOI: $10.3923 /$ crpsaj.2011.1.11

[20] Jing, H. and Shively, G. (2012). A review of Agriculture, Food Security and Human Nutrition Issues in Uganda. 2-10

[21] Kitalyi, A.J. (1998). Village chicken production systems in rural Africa: household food security and gender issues. FAO Animal Production and Health Paper 142, Rome, Italy.
[22] Mugga, R. (2006).Ugandan industry thriving, Word Poultry.22, 8

[23] Mugga, R. (2009). Modern breeds find their way to Uganda. WordPoultry, 25 (2).8.

[24] Nurul. H., Ooi.J.L., Yong.C.P. and Tina.N. (2010). Effect of Chicken and Duck Meat Ratio on the Properties of Sausages. International Journal of Poultry Science, 9(6).550-555.

[25] Okoli, I.C., Anyaegbunam, C.N., Etuk, E.B., Uchegbu, M.C. and Udedibie, A.B.I. (2004). Socio-economic Characteristics of Poultry Business Entrepreneurs in Imo State, Nigeria. Journal of Agriculture and Social Research, 14 (2).

[26] Smith, J. A. (1990). Poultry. Centre for Tropical Veterinary Medicine. University of Edinburgh.

[27] Sonaiya, E.B., Branckaert, R.D.S. and Gueye, E.F. (1999). Research and development options for family poultry. Introductory paper to the First INFPD/FAO Electronic Conference on the Scope and Effect of Family Poultry Research and Development (Gueye,E.F.,Ed).http://www.fao.org/waicent/faoinfo/agricult /aga/agap/lpa/fampo1/intropap.htm. Accessed on $12^{\text {th }}$ January, 2013.

[28] UBOS (2009). Uganda Bureau of Statistics report 2009. Kampala, Uganda. Unpublished report.

[29] UBOS (2010). Statistical abstract, 2010. Uganda Bureau of Statistics. Kampala, Uganda.

[30] United Nations Development Programme (UNDP), (2012). Africa Human Development Report: Towards a Food Secure Future. www.afhdr.org accessed on $12^{\text {th }}$ January, 2013.

[31] USAID (2010). Parternership for Safe poultry in Kenya (PSPK) Program. Value chain analysis of poultry in Uganda.

[32] Wainaina, P. W., Okello, J. J. and Nzuma, J. (2012). Impact of contract farming on smallholder poultry farmers' Income in Kenya. Selected Paper prepared for presentation at the International Association of Agricultural Economists (IAAE) Triennial Conference, Foz do Iguaçu, Brazil, 18-24 August 